\title{
RESEARCHING THE SPATIAL ASPECTS OF THE ROMANI- HUNGARIAN COEXISTENCE BY THE MEANS OF MENTAL MAPPING
}

\author{
Melinda MOLNÁR ${ }^{\mathrm{a}}$, Tünde BOGÁRDI ${ }^{\mathrm{b}}$ \\ ${ }^{a}$ Szent Istvan University, Faculty of Economic and Social Sciences, Address: 2103 Gödöllö, Páter K. u. \\ 1., phone: +36-30/531-8517, e-mail: nagyne.molnar.melinda@gtk.szie.hu \\ ${ }^{\mathrm{b}}$ Szent Istvan University, Enyedi György Doctoral School for Regional Sciences, Address: 2103 Gödöllö, \\ Páter K. u. 1., phone: +36-20/594-9220, e-mail: bogarditunde@gmail.com
}

Cite this article: Molnár, M., Bogárdi, T. (2016). Researching the Spatial Aspects of the RomaniHungarian coexistence by the Means of Mental Mapping. Deturope, 8, 3: 170-184

\begin{abstract}
In our study we shall analyse the spatial aspects of the Romani-Hungarian coexistence based on the field research results of the village seminar workshop organized by the Szent István University (Gödöllö). We present two different situations: one segregate analysis using Baks as an example, where we find a settlement considered as majority, and a Romani segregate; and provincial ghettoization using Átány as an example, where due to a previous site termination the Romani people dispersed over the whole village area. We conducted surveys in both settlements in order to find out the local residents' opinion on the development of the value of the inhabited area. Our goal on the one hand is to present the method of ethnicity analysis by mental mapping in rural areas, and on the other in addition to offering methodological practices is to point out a few important takeaways of the spatiality of the RomaniHungarian coexistence based on our actual experiences.
\end{abstract}

Keywords: mental mapping, Romani-Hungarian coexistence, segregate, ghettoizing

\section{INTRODUCTION}

Though the method of mental (cognitive) mapping was not particularly developed for researching the coexistence of various social groups, still it is able to deliver useful information. When performing mental mapping, we always gather information regarding the space that surrounds us in a way to understand how it is viewed and perceived by the individual / examined group. The purpose of these kinds of researches is to receive deeper knowledge about the examined group's own internal world and surrounding external world. As said by Roger M. Downs and David Stea (1973): cognitive mapping is an abstraction which includes all cognitive and mental abilities, with the help of which we are able to collect, arrange, store and map the information regarding the space that surrounds us. Therefore a mental space generated by mental mapping is sort of a conscious image of the reality, and various associations are attached to these mental spaces (Letenyei, 2006) when 
they are created. Mental researches can just as well identify psychical actions as spatial processes. The purpose of this study is to get to know a social phenomenon (RomaniHungarian coexistence) with spatial dimensions.

\section{Mental mapping and analysing ethnicity in Romani-Hungarian coexistences}

The application of mental mapping in spatial researches enabled us to realize that a settlement (or even a larger region) is made up by various mosaic pieces, or special areal units divided by borders. These confines are not necessarily the same as the lines marked on a map, but they definitely separate areas which are clearly characterized by their own special socialcultural atmosphere. In this field, we have a rather large experience regarding urban researches, which knowledge can become useful in practice as well, if these experiences are incorporated in the practices of urban planning and urban marketing.

There is no single method for performing mental mapping. There are quantitative data recordings, with the purpose of measuring the recognition of certain elements of the space which are perceived objectively, completed with the stereotypes of respondents. Qualitativebased mental mapping is a soft method, which is mostly based on participant observation. It is possible to use ready-made maps or photos as a start, but making participants draw a map is also part of the mental mapping practice. Ferencz G. (2013), referring to Kevin Lynch (1960) believes that performing an analysis on the name and extension of the examined space (spatial units), researching fracture lines and borders, and understanding orientation points, routes and junctions all deliver important information for mental mapping, depending on the emerging problem/phenomenon.

Compared to mental researches performed in urban areas, mental mapping conducted in rural areas are limited by the fact that the space is much more uniform in terms of its social, economic and technical parameters. Another distinctive characteristic is that the general everyday space of activities and the cognitive space are both much smaller than in urban areas. (Cséfalvay, 1994)

This study demonstrates how an ethnicity-analysis can be performed by the means of mental mapping in rural areas. But first, what do we mean by the phrase ethnicity? By following the definition of Clifford Geertz (1973), it is a commonly agreed upon and publicly expressed personal identity, resulting in a coexistence which is not fixed, but depends on the actual situation, and appears differently in various social interactions (Kovács, Vidra, and 
Virág, 2013). Since ethnicity has a social imprint (Jenkins, 1997), its "visible and invisible confines" are also clearly laid out. We agree with the thought of Kovács, Vidra, and Virág (2013) that “... the fact whether these borders are occasional or permanent, clear or blurry, passable or impassable, and the extent to which they determine the village and its environment primarily depends on the current self-reproduction opportunities (ecologic and economic conditions) and abilities (available practices and knowledge) of the specific local society." (Kovács, Vidra, and Virág, 2013: 80). Our goal is to interpret it within the RomaniHungarian coexistence. The examination of this phenomenon is relevant, and understanding the operation of such borders greatly contributes to the prevention of an outcome possibly resulting in conflicts.

\section{OBJECTIVES AND METHODS}

Throughout the field work, we started off with the fact that the spatial arrangement of the Romani minority also has an effect on the value of the settlement as a space. For the mental mapping analysis we have personally conducted a questionnaire survey, with the objective of having a sample from about every fourth household (from every street of the two selected settlements, in proportion to the number of their population). In case of Átány we have managed to fill out 107 questionnaires, and at Baks, the number was 155. The questionnaire survey was performed within the frame of the Village-seminar activity of the Szent István University and its summer field research. One of the two examined locations was Átány (Heves county) which we already visited in 2014, and the other settlement was Baks (Csongrád county), where we conducted our survey in 2011.

As to the selection of the research locations for this present study, our principle was to have one example on a segregation of the Roma population, and another where the RomaniHungarian coexistence is characterized with a spatially scattered position of the Roma people. Baks was selected to fit the former, where the segregation of the Romani population is a part of the settlement with a specific name (Máriatelep), which though was not always a segregate, however currently $90 \%$ of the Roma population of the village lives there. Átány on the other hand is an example for the spatially dispersed coexistence of Romani and Hungarian people. Decades ago, the local Roma community lived at the Mákos-telep part of the settlement: though spatially divided, still in symbiosis with the majority of the society. However, based on the decree of the Hungarian Socialist Worker's Party Political Committee accepted on the 
$20^{\text {th }}$ June 1961 about "Various tasks intended to improve the situation of the Roma population", the Mákos-telep site has been terminated. The authors Fél-Hofer recite that there were a number of incentives offered by the state for the Roma population at Átány as well to move into the village. One of the most important of these incentives was the long-term interest-free government loan, which people could apply for if they "planned to build a permanent Hungarian-style house in the village". As a result of these supports, in 1964 there were five houses owned by Roma people, where eleven family lived, and as the authors observe, "the living conditions (...) were not that much different from the crowdedness of the "gipsy-like" habitats" (Fél and Hofer, 2010: 258). Earlier, the majority of the Roma population did not live in the village, but at a site located in the outskirts of the village. By 1975, with the help of government aids, these Roma people who had been living in a ghettolike environment were re-settled in the village. Concerning site terminations Virág (2010:64) explains that as their result ,two groups, which interact with each other within the society of the settlement, but are very different in both cultural and demographic aspects, have been placed very close to each other spatially". This caused an intensified population exchange, forcing a part of the former community to all but flee, and as a result it launched the ethnic homogenization ("gipsyfication") of these parts of the settlement (Cserti Csapó, 2011). Durst (2010) - drawing a parallel between the site terminations of the 1970s and the 2000s presents the example of the small village of Lápos, Borsod-Abaúj-Zemplén County: ,in the name of the integration of the Romani populace they managed with government funding to convert Lápos into a village exclusively populated by Romani people" (Durst, 2010: 34).

As to the size of the two settlements: Baks is inhabited by 2300 people, and Átány has a population of 1500 . Regarding the Romani-Hungarian coexistence, their history goes back to centuries in both cases. Another common feature of the settlements is that the two types of population have two different age-structures. The Roma population is basically of a young age-structure, while the majority of the society is ageing. There is a difference however in the numbers regarding the Roma population (their proportion within the population). Hereby I would like to note that in Hungary there are no valid, useful statistical data available on the Roma population, since they are based on self-certification. Therefore at both locations we started off using the opinion of the management of the settlement, and the estimates provided by the background documents of regional development concepts. In case of Átány, the ratio of the Roma population should be about $40 \%$, and in case of Baks, it is about $25 \%$. 
The question we have used in order to examine the changes within the value of the space and its ethnic relevance in case of Baks (where there is an independent Roma segregate) was: "Is there a difference between the various parts of the settlement? In what ways are they different?". And in case of Átány, where the Roma population lives dispersedly in the settlement, the questions was: "In which parts of the settlement would you prefer to live / would definitely not want to live? Why?"

\section{RESULTS}

\section{Átány and the spatially dispersed Roma ethnicity}

In the past decades, the previously neat image of the village vanished; the amortisation of the built environment obviously demonstrates the decaying process of the village. For its examination, we have evaluated the residential real estates of the village based on a field research performed in 2014. (Vitéz, 2014) It was apparent that the state of the properties located at the centre of the village is better, newly renovated and built houses can also be found here. However as shown on Fig. 1, there are more parts of the settlement which are scarcely habited. It is typical in case of these perishing zones that empty and deserted estates became the victim of illegal house demolition. In the past decades more than 150 houses had the same fate, which means that entire streets disappeared.

The amortization of the houses shows a correlation with the spatial condensation of the local Roma community, meaning that these perishing parts of the settlement are also becoming ghettos. It is worth mentioning that the mayor reports on 15 ghettoizing parts within the settlement. Based on the results of our field researches, these are also forming blocks: their numbers become lower, but they transform into ghettoizing parts of the settlement of larger size. (Fig. 1) It is probable that should we be able to view a similar street-image analyses from the beginning of the 2000's, we would see a greater number of ghettoizing points, which have since transformed into blocks. Unless this process is stopped, the amortization of the village will continue, and other streets and houses will keep on perishing. 
Figure 1 Perishing parts of the settlement at Átány

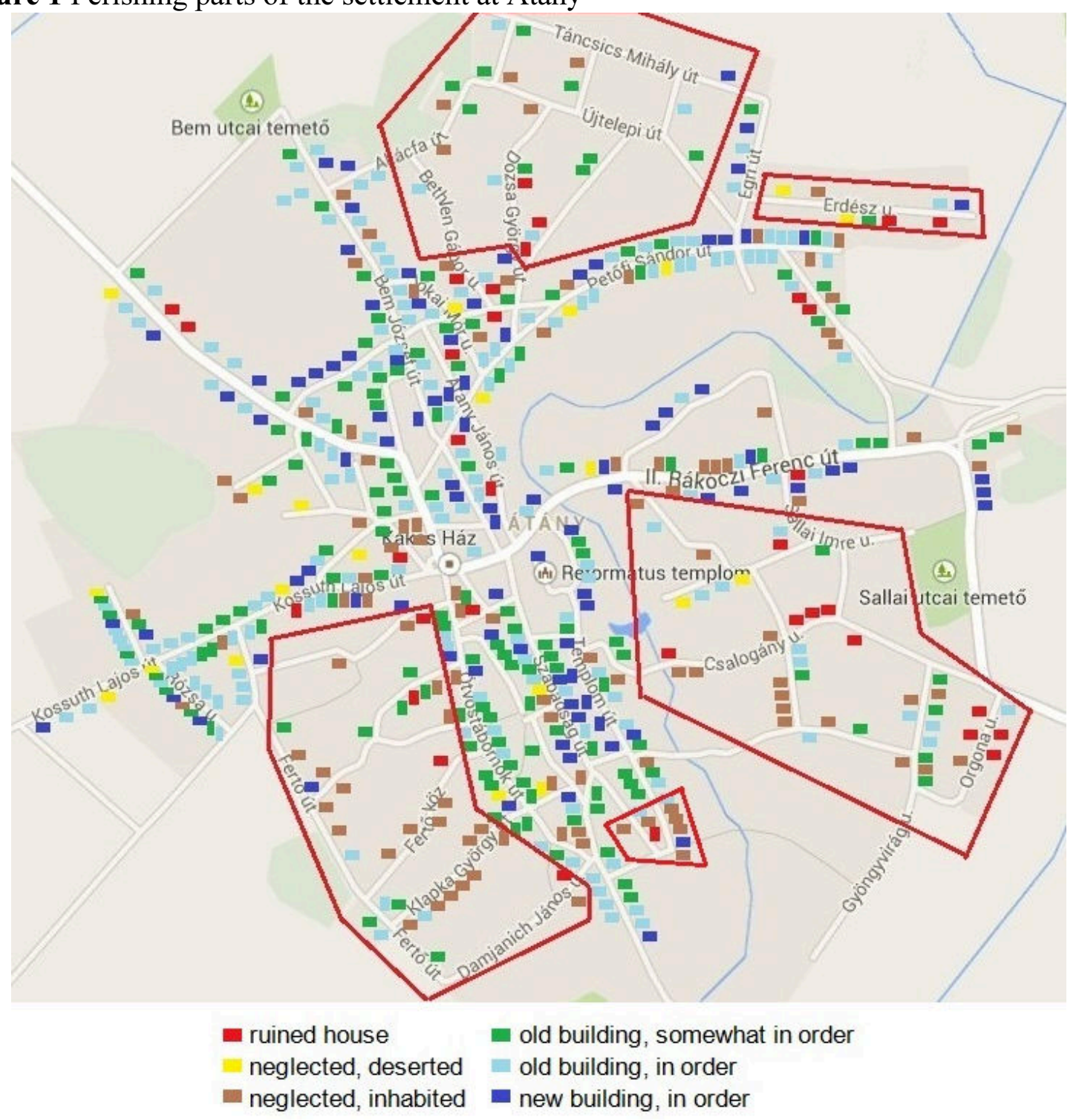

Source: Prepared by Vitéz - Bogárdi

\section{The result of the mental mapping of Átány}

During the questionnaire survey we have examined the parts of the settlements where respondents would prefer to live, and where would they not prefer at all. 
Figure 2 Streets in Átány where residence is preferred and where it's not

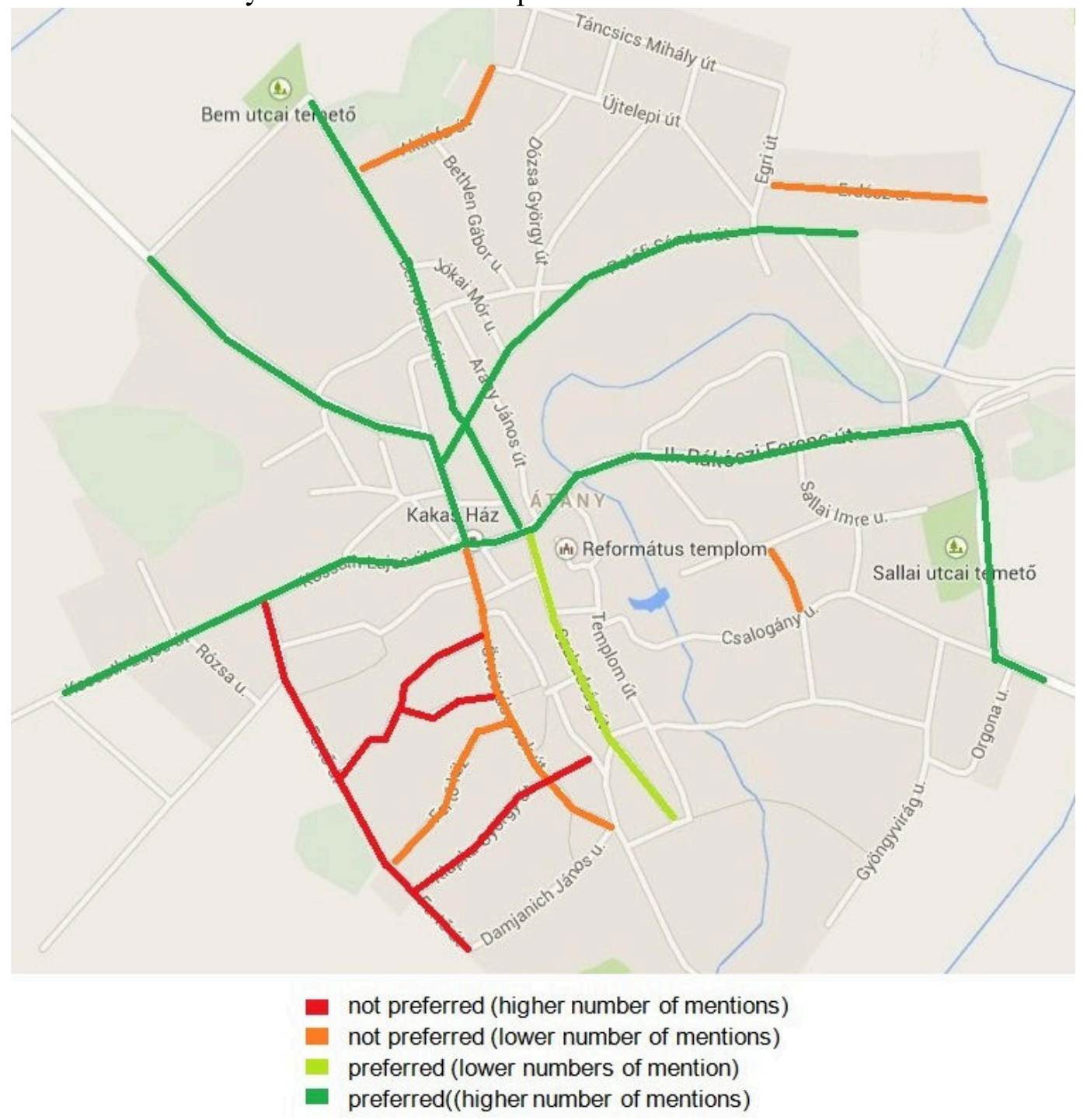

Source: Prepared by Bogárdi

We can see that the most preferred streets are located in the centre. Among the 98 mentions we received from 60 respondents the most popular was Bem street (23 mentions), while 18 respondents selected Rákóczi street as a positive example (which is the main street of the village). Petőfi street was mentioned 15 times, and Kossuth 11 times. Szabadság street was mentioned by 7 respondents (Fig. 2). It is important to note here that some of our respondents were not able to name streets, they only mentioned that the centre of the village is a preferred part of the settlement, it is in a better situation. We also believe that it was important to explore the reasons why respondents would prefer/not prefer to live in certain streets of the village. Based on the arguments in relation to the preferred streets, it is clear that the major reasons are the relatively good public safety, emotional attachment and the lower proportion of the Roma population. 
The zones marked with red and orange borders (not preferred zones) were established based on 104 mentions from 45 respondents. 34 other mentions featured parts of the settlements which are hard to exactly determine (such as "the edge of the village" or the "Kömlö part", while others said the "neighbourhood" of a not preferred street). We recorded 14 unintelligible answers as well, those respondents would not prefer any part of the village, saying "everywhere is bad", "there is trouble everywhere" or "none of the streets are liveable". The most people who talked about non-preferred streets selected the Klapka and Fertő streets (10 mentions each), and the Ötvöstábornok street (9 mentions). Árpád and Dobó received 7-7, Gyöngyvirág (formerly Lenin) 6, Bem and Csalogány 5-5, and Erdész street received 4 mentions in total. Reasons for not preferring these streets clearly demonstrate that respondents would not want to live in streets habited by the Roma population, they have a problem with public safety, and the decay and destruction of the built environment.

Besides mental mapping we carried out problem perception analysis as well. Among the 107 respondents 101 people could name a problem with the settlement. Among the 151 answers made by them 54 were connected to public order and safety, which were followed by 34 mentions of the Romani populace, and 32 of unemployment. Thus it is clear that within the set of problems prominent are the disadvantaged situation of Átány, social exclusion, and the issue of ethnicity perceived as the originator of these problems.

We also conducted vision-analysis to supplement the results and experiences of mental mapping. According to Győri-Nagy (2003: 7) its importance lies in the fact that „The vision of the local residents - despite the fact that the local population is unlikely to break out from its structural captivity on their own - is decisive regarding the future of the village and the area", since ,the whole settlement's capability of future and the solution models and levels of its accumulated problems are decided by the quality of the actual or possible intellectual bases and reserves of the given settlement".

Regarding vision we asked the respondents the question „How do you imagine Átány 20 years from now?". The results painted an extremely pessimistic picture, only every $10^{\text {th }}$ respondent were hopeful regarding the future of Átány. The majority of the respondents expect continuous social exclusion and ghettoizing in the future of the settlement and the area:

- ,the gipsies will be here, the Hungarians will vanish”

- ,it's a gipsy camp, the old people will die out, and that's it”

- ,only gipsies will remain”

- ,nothing will be here; gipsies, that is”

- "Nothing will be here only a slum: the same will happen what happened with Kömlö and Tiszanána on the account of the gipsy population." 
- ,gipsy village; the area and Heves County both”

Or in other words the majority of the respondents mentioned intertwined social, economic and environmental erosion, while others saw depopulation in the near future. (However, this latter scenario is unlikely. Despite the drastic depopulation experienced over the last 80 years, the Romani population's inclination to childbearing and high birth rate makes this possibility rather implausible.) Thus instead the withering away of the village a ghettoizing process can be predicted in the future based on the demographic data.

\section{Baks and the Roma segregate: The spatial characteristics of the local segregate}

Baks is a village which consists of three individually named parts, which are: Major, Szőlö, Máriatelep. The fact that these three parts of the settlement also appear as separate parts in terms of local identity is well demonstrated by the answers provided by the 155 households: $71 \%$ of them clearly identified (and explained its reasons) that there are differences amongst the various parts of the settlement.

The centrally located part of the village: Szölö. This represents the "centre" of the village, in a geographical and functional meaning as well. Practically all institutions are located here, and the service providing sector is also established here the best. The most important institutions and facilities can be found here: elementary school, village house, mayor's office, marketplace, central bus station, church, a number of general stores, restaurants, ice cream parlours. This place is considered to be the spatial junction of villagers. It means that the majority of Baks residents practically turn up at this place every day, irrespectively to where they actually live. The developments of the past years are also the most apparent in this part of the village: the establishment of a playground, a park and a parking place, the renovation of the elementary school, and the construction of a catholic church. The other part of the village, the Major is also in a good situation, however its noteworthy sites only include the gas station and the cemetery. However, it has its own bus stop. Máriatelep does not even have one, it is an area with a totally different image. The road leading there is also a dead end. Only those people go there who has business to do there. There is no trespassing traffic. It is also separated physically from the other two parts of the village, as there is about a one and a half kilometre long uninhabited zone dividing it from the centre of the village. (Naturally there are geographic reasons for being so distinctly far away from the centre. Between the parts Szőlö and Máriatelep there is a reedy swamp field called Dongér, which is unsuitable for habitation.) In this part of the village there is only one store. There is no public transportation, no drainage canal system or sidewalks. The majority of roads and streets are not even paved with concrete. Its separation is further enhanced by the concentration of the Roma minority in 
this area. About $95 \%$ of the current population of the minority residing in the village lives here. (Kistamás- Molnár, 2011) (Fig. 3)

Figure 3 The structure of Baks

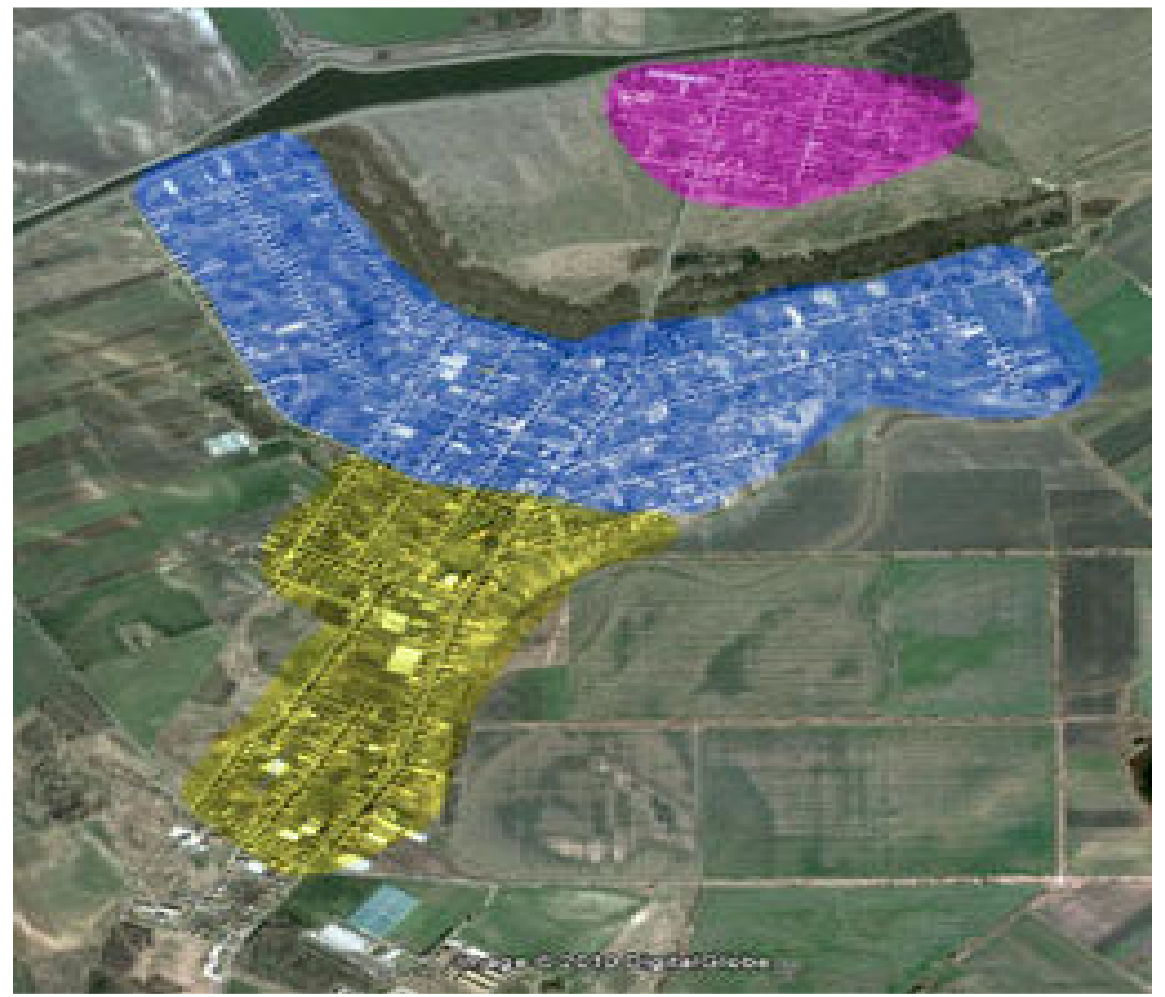

Note: yellow: Major, blue: Szőlő, pink: Máriatelep

Source: Prepared by Molnár

\section{The result of the mental mapping of Máriatelep}

The perception of Máriatelep is summarized in Tab. 1. The opinion about this part of the village is quite unanimous in case of both those who live at Máriatelep and those who live elsewhere: the situation is critical. For the "outsiders" this part of the village basically represents the site for being the "problematic" part of Baks, however mostly the same opinion appears in the answers of those who live at Máriatelep. In relation to judgments with social relevance it must be noted that people who live at Máriatelep perceive their own community in a less objective way. Though it has been mentioned that there is cohesion in this part of the village, yet its opposite was emphasized at least to the same extent in the opinions received. The reason why it is important to point this out is because poverty and a neglected environment do not necessarily have to result in a contradicting, fractured society. Certain opinions from Máriatelep claim that this was not always the case there. The place was characterized by a smooth coexistence between the Roma and the Hungarian people for centuries. From the discussions conducted with relevant people it was revealed that conflicts 
first appeared within the community when new families appeared from "elsewhere" (not from Baks), who were not familiar with the traditional social norms.

Our researches clearly show that the perceived image of Máriatelep according to those who live at Szőlö or Major can be described with the following characteristics.

- for "outsiders" Máriatelep represents the site for being the "problematic" part of Baks

- the problem is not only triggered by the lack of infrastructure, but by the structure of the society as well, meaning that the Roma community is concentrated there.

By analysing the opinions from mainly Roma people at Máriatelep separately, the following conclusions can be made

- the perception of the residents of Máriatelep about themselves and their own living environment is quite mixed (there are positive and negative elements as well).

- the once peaceful coexistence of the Roma and Hungarian people at the site was upset by the arrival of outsider families who disregarded the social norms.

Table 1 Opinions about Máriatelep

\begin{tabular}{|c|c|c|}
\hline $\begin{array}{l}\text { What residents of Máriatelep } \\
\text { think about Máriatelep }\end{array}$ & $\begin{array}{l}\text { What residents of Szőlö think about } \\
\text { Máriatelep }\end{array}$ & $\begin{array}{l}\text { What residents of } \\
\text { Major think about } \\
\text { Máriatelep }\end{array}$ \\
\hline \multicolumn{3}{|c|}{ Evaluation from the aspect of infrastructure } \\
\hline $\begin{array}{l}\text { The least developed part } \\
\text { Lack of parks } \\
\text { Neglected } \\
\text { Application for aids from a } \\
\text { disadvantaged situation } \\
\text { No playgrounds } \\
\text { Poor selection at the store, and high } \\
\text { prices } \\
\text { No entertainment opportunities } \\
\text { Houses are not renovated } \\
\text { The most untended } \\
\text { No establishments } \\
\text { Separate part } \\
\text { The local government fails to perform } \\
\text { public duties: no ditches, snow is not } \\
\text { ploughed } \\
\text { Lack of pavement } \\
\text { Slow development } \\
\text { Earlier it was not ugly or something to } \\
\text { despise }\end{array}$ & $\begin{array}{l}\text { Separate from the other parts } \\
\text { Gardens are untended } \\
\text { Backwards, poor part of the village } \\
\text { Far from the centre } \\
\text { Less attention on it } \\
\text { End of the village } \\
\text { Neglected } \\
\text { Poor infrastructure } \\
\text { Waste management is almost } \\
\text { unresolved } \\
\text { Many new houses are built here } \\
\text { Eroded } \\
\text { Not enough stores } \\
\text { Much more garbage } \\
\text { The most disadvantaged part, because } \\
\text { of the Roma community } \\
\text { A waste land, far from the centre } \\
\text { I would not want to live there }\end{array}$ & $\begin{array}{l}\text { It is eroded } \\
\text { Backwards, poor } \\
\text { part of the village }\end{array}$ \\
\hline
\end{tabular}


Table 1 (continued)

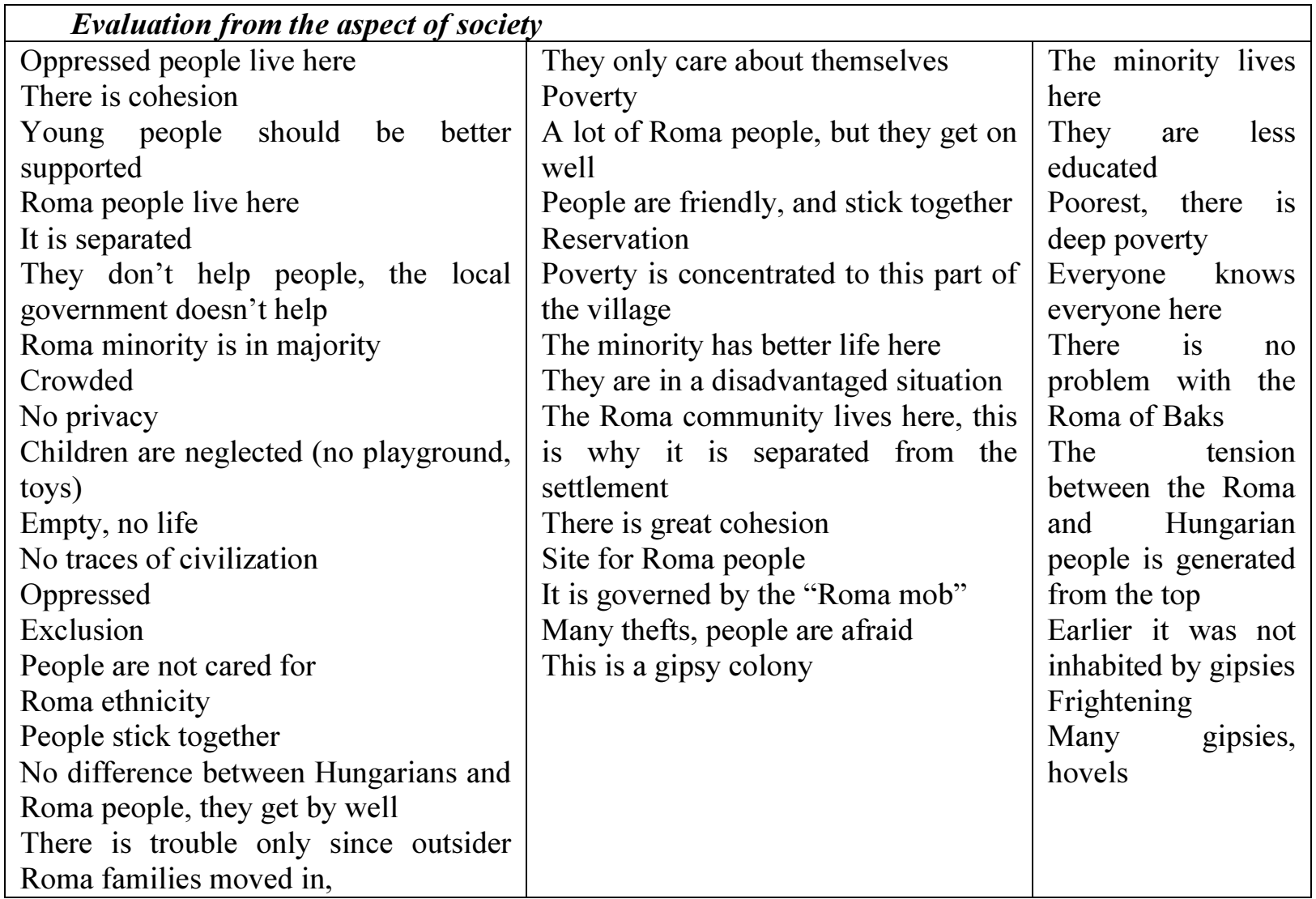

Source: Kistamás T.- Molnár M. $(2011,87)$

\section{CONCLUSION}

Our field research experiences in relation to the coexistence of Romani and Hungarian people demonstrate that streets, parts of streets or parts of the village of negative and positive value are separated in the minds of people. Negative values are closely linked to the spatial location where the Roma community resides. In regions where the two ethnic groups are separated visually as well (in case of Baks there is a one and half kilometres long uninhabited barren land), the physical separation always results in mental segregation.

If we analyse the opinion of the majority of the society and of the Roma community regarding their coexistence, experiences show that generally the majority of the society perceives the space inhabited by Roma people to be quite alike in their own internal thoughts. They do not think that the space inhabited by Roma people can be actually different even if the living conditions are visibly not alike everywhere. The majority of the society uniformly perceives the area where the Roma community resides in a negative way, coupling it with words such as "misery", "poverty", "crime". There are however a few important differences between the Romani-Hungarian coexistence in the segregated area and in the dispersed situation. In case of the dispersed situation, the majority of the society expands the actual 
borders of the ethnic space with a buffer-zone - or a temporary space, after Németh (2015). It means that they project their negative judgement to areas which are not inhabited by Roma people, but confine with them. In case of a segregate it frequently occurs that the majority of the society forms an opinion about the living conditions of the Roma community without having actual experiences. Indeed, in many cases they had never been there, or not since years.

When analysing the opinions of the Roma community about the micro-world that surrounds them, experiences show that they sense that the judgement of the settlement is not homogenous. Similarly to the answers provided by the majority of the society, the Roma community also paints a "negative" image about their own living space. However they do not consider their living space to be uniformly negative at all. It is a general truth that everyone evaluates their own habitat in a better way. We also experienced that the Roma community do not perceive their own habitats to be uniform, because they do not perceive their community as a single unit.

According to our experiences, the commencement of the process of ghettoization is usually facilitated by spatial segregation, however it must be noted that not all segregates become automatically ghettos. It actually depends on a number of ecologic and economic factors (Kovács, Vidra, and Virág, 2013). Another fact learned from experiences is that a ghetto can not only form in a segregate. A spatially dispersed Roma ethnicity can also create a ghetto, if they form a mass block and result in a large social, economic and environmental destructionzone.

Finally, we learned that an ethnic space is not only drawn up by the visual borders of habitats. It appears on other levels as well regarding everyday contacts. For example in school life, or in the formation of the clientele of a store. The latter also means that some of the service providers (especially general stores) specialize in servicing Roma people, frequently completing their activities with offering loans or usury. In schools, the confines of ethnic spaces are apparent in "Roma classes". At Átány, the ever growing ratio of the Roma population within the local youth also contributed to the fact that the leadership of the village approved of the establishment of another school besides the existing public school, which serves as a viable alternative for active well-to-do families with young children. An option which helps them to avoid having to send their children to the socially degraded, dangerously conflicted public school or to neighbouring settlements. It is a church school, which though do not exclude the enrolment of Roma children, on account of having to pay an allowance to the church and of the obligations specified in a strict policy, in the end it resulted in a church 
school which in most cases cannot be afforded by Roma people (Kassai, 2014). (Naturally, not only Hungarian children can be enrolled into this school. Children with better abilities of both Hungarian and Roma origins are enrolled in the Reformed school by their parents).

Visible and invisible confines come in various forms. Furthermore, they appear differently in each case. We must take note of their existence and operation, since they define the extent to how the community of a settlement is able to create a viable environment in the present and in the future.

\section{REFERENCES}

Cserti Csapó, T. (2011). A cigány népesség a gazdasági-társadalmi térszerkezetben. (The Romani population in the social-economical spatial structure). Pécs: PTE BTK Oktatáskutató Központ, Virágmandula Kft.

Cséfalvay, Z. (1994). A modern társadalomföldrajz kézikönyve. (Handbook of modern social geography.) Budapest: IKVA.

Downs, R. M., \& Stea, D. (1973). Térképek az elmében. (Maps in the mind.) Downs, R. M.Stea, D. Cognitive Maps and Spatial Behavior: Process and Products. In: Downs- Stea (Eds.) Image and Environments. Chicago: Aldine.

Publishing: (http://mmap.integratio.ro/pdf/6mentmap.pdf), 149-150.

Durst, J. (2010). „Minden évben máshogy fordul a világ” A telepfelszámolástól a szegregált cigányfaluig. („The world turns differently in every year” From site termination to a segregated gipsy village.) In: AnBlokk. 2010/4. 34-38.pp.

Ferencz, G. (2013). Lakóhely iszegregáció és mentális térkép Szegeden (2008). (Segregation and mental mapping at Szeged (2008).) In: Rácz, A. (szerk.) Város és vidéke. (Town and its province.) Településszociológiai tanulmányok 2, 65-103.

Fél E., \& Hofer T. (2010). „Mi, korrekt parasztok...” Hagyományos élet Átányon. („We, proper peasants ..." Traditional life at Átány.) Budapest: Korall.

Geerts, C. (1983). Local Knowledge: Further Essays in Interpretive Anthropology. New York: Basic Books.

Győri-Nagy, S. (2003). Jövőkép(esség)ek. (Visions and capabilities of the future.) Budapest: Kölcsey Intézet.

Jenkins, R. (1997). Rethinking Ethnicity: Arguments and Explorations. London: Sage.

Kassai, Zs. (2014). A civil aktivitás jellemzői Átányon. (Characteristics of civil activities at Átány.) In: Acta Regionis Rurum. 2014/8, 52-63.

Kistamás T., \& Molnár M. (2011). Baks mentális térképe. (Mental map of Baks.) In: Acta Regionis Rurum. 2011/5. 83-91.pp.

Kovács, É., Vidra, Zs., \& Virág, T. (2013). Az etnicitás reprezentáció és mindennapi gyakorlatai. (Representations and everday practices of ethnicity.) In: Kovács, É., Vidra, Zs., Virág, T. (szerk.) Kint és bent/ Lokalitás és etnicitás a peremvidékeken. (In and out / Locality and ethnicity at the peripheries.) Budapest: L'Harmattan Kiadó

Letenyei, L. (2006). Településkutatás I. (Settlement research I.) Budapest: ÚjMandátumRáció.

Lynch, K. (1960). The Image of the City. Cambridge MA: MIT Press. Products. In: Downs, R.M., Stea, D. (Ed.): Image and Environments. Chicago: Aldine.

Publishing.http://mmap.integratio.ro/pdf/6mentmap.pdf 149.p. (2011.10.05.)

Németh, K. (2015). Szegregátum vagy etnikus szomszédság? Egy dunántúli kisváros „szegregátuma” a diskurzusok és köznapi cselekvések tükrében. (Segregate or ethnic 
vicinity? The "segregate" of a Transdanubian town in the light of discourses and everyday actions.) In: Virág, T. (szerk.) (2015). Törésvonalak. Szegénységés etnicitás vidéki terekben. (Fractures. Poverty and ethnicity in provincial spaces.) Budapest: Argumentum Kiadó.

Virág, T. (2010). Kirekesztve. Falusi gettók az ország peremén. (Cast out. Village ghettos on the edge of the country.) Budapest: Akadémiai Kiadó

Vitéz, B. (2014). Átányi utcakép. (Street image of Átány.) In: Acta Regionis Rurum. 2014/8. 76-85.pp. 